\title{
The Role of Women in Maji Maji War from 1905 to 1907 in Matumbiland, Ngindo and Ngoniland War Zones, Tanzania
}

\author{
Athanasy Gregory, PhD Scholar \\ St. Augustine University of Tanzania \\ Corresponding Author: athanasygregory@gmail.com
}

\begin{abstract}
This paper explored the role of women in Maji Maji war of 1905-1907, which was carried in Matumbi land/Ngindo areas, especially at Nandete village, Kibata village and Kilwa-Kipatimu in Lindi Region where the event started and in Ngoni land at Mahenge area, Old Igumbiro village, Kitanda village, Namabengo village, and Peramiho area in Ruvuma Region where the war ended. A qualitative research design was employed through an in-depth interview method to gather specific information on the role of women in the Maji Maji war. Secondary sources were obtained from libraries and memorial museums and YouTube historical clips transcription as well as short film historical analysis were also used. Content analysis was used to explore and analyze the role assumed by women in the Maji Maji war. The study revealed that women in the Maji Maji war of 1905-1907 played a pivotal and nationalistic role through planning, organizing and dividing strategic war zones. Some women carried and distributed the Maji-Medicines to the Maji Maji fighters in the fighting camps. Moreover, women prepared and supplied food to the Maji Maji fighters which enabled them to prolong fighting with their rivals - Germans despite the poor weapons the natives were using. The researcher recommends that for Tanzania to strive and ensure fair and progressive society, women should not be left behind and neglected in the reconstruction of its objective historical knowledge. They should be effectively used in building the economy of the nation by being given positions in both government and non-government organizations.
\end{abstract}

Key words: Historiographies, Women, Maji-medicines, Maji Maji War, Matumbi land, Ngindo, Ngoniland

\section{Introduction}

Throughout history, women have been perceived differently basing on cultural norms, among other factors. Unlike the patriarchal societies, in matrilineal societies, offices and wealth are occupied by the female line. For instance, among the Tonga in West Africa, women chiefs controlled very limited units of production. However, around 1900, a woman chief named Mammy Yoko, in the interior of Sierra Leone, made a powerful confederation. The tradition of women chiefs was also observed in pre-German central Cameroon, among the Flup of Casamance in South Senegal and among the Mende and Sherbro of Sierra Leone (Coquery-Vidrovitch, 1997). Between 1914 and
1970 , out of 146 recognized chiefs in Sierra Leone, where patriarchal system dominated, there were 10 women chiefs. This indicates that during both precolonial and colonial eras, women were not left behind in making history.

More importantly, around 1610, Queen Nzinga Mbande (Mbundu) of the Ovimbundu in present day Angola, an eminent heroine of the slave trade and political activist, built a strong fortress in her dominion, Kongo Kingdom, which made the Portuguese fear her because she was able to conduct open warfare when required. Additionally, she consolidated her power as a tembanza with a Jaga chief named Kasanje - a political alliance between the two leaders until the Jaga allied with 
the Portuguese to pillage her capital (CoqueryVidrovitch, 1997). This indicates that Queen Nzinga fought tooth and nail to preserve the sovereignty of her dominion.

Before the coming of colonialists, the Makua, the Yao, the Makonde and the Mwera of Southeast Tanzania experienced matrilineal lineage (Kumiko, 2008) although history does not take into account for the specific time when the ethnic groups established their settlements. The people of Southeast Tanzania are historically related to the matrilineal people of Mozambique and Malawi because they were centrally governed (Kumiko, 2008; 2014). Clans which were the basis of the societies were headed by female members who were entitled as female clan heads. In practice, most of the land also belonged to the maternal clan. During the colonial period and even beyond, there were resistances organized by women due to their economic power. Women from West Africa and some of the South African women were recorded defending the rights that were being swept away by the colonizers (Coquery-Vidrovitch, 1997). These findings suggest that women were powerful because they were able to assume political roles.

Since the struggle for Tanganyika's independence to the post-independence period, women have been marginalized by being denied political space to demonstrate their leadership capabilities (Anyimadu, 2016). This is confirmed by Hon. Samia Suluhu Hassan, the Vice President of the United Republic of Tanzania, who was quoted saying that she was lucky by being nominated to contest for the position of Vice President (Egboh \& Aniche, 2015). It means that in spite of deliberate measures taken by the ruling party in post-colonial Tanzania to promote gender equality, the political space for women is still limited as Samia was the first female Vice President. Besides Samia Suluhu Hassan, several other women played various roles toward the Tanzanian history. Bibi Titi Mohammed, for example, became the head of the Tanganyika African National Union (TANU) Women's wing where she attracted 5,000 women to join the party. She used women's cultural and economic networks to mobilize, exchange information, sell party membership cards, announce rallies, organize matches and raise money for TANU (Egboh and Aniche, 2015;) which went to become the freedom party of modern Tanzania.
In the earliest secondary nationalist resistance struggle in German East Africa, Tanganyika, both men and women warriors organized themselves to fight the Germans in the Maji Maji war (Shiraz, 1984; Rushohora \& Kurmann, 2017). They were drawn from about 20 different ethnic groups such as Matumbi, Ngindo, Pogoro, Mwera, Yao and Ngoni, just to mention a few (Rushohora, 2005). Narrators of history keep saying that women were in the frontline fighting for their lost freedom (Elijah, 2010). However, little is known and less attention has been put into writing about the bibliographies of female warriors engaged in the Maji Maji war. This marks the essence of exploring the role of women in the Maji Maji war, 1905-1907 of Ungoni and in its epicenter in Matumbi land/Ngindo area.

Selection of the study topic relies on several historical reasons. Firstly, the Maji Maji war of 19051907 was fought by different Tanganyika's ethnic groups organized by charismatic leaders such as Ndimi Omcheka, Ngurumbale Mandai and Mtemangani of Kilwa, Kinjekitile Ngwale of Ngarambe-Rufiji, Chief Chabruma, and Nduna of Songea against German colonial rule (Rushohora, 2005). Basically, the German colonial rule forced Tanganyikans to produce cotton and tobacco plantations with either low or no payment (Rushohora \& Kurmann, 2017). As a result, the war broke out on $15^{\text {th }}$ July, 1905 at Nandete village in Matumbi land/Ngindo areas in Kilwa District, and ended at Mahenge area in Songea in 1907 where the Germans' superior weapons defeated the Tanganyika's poor weapons (Kentake, 2015) and the Germans colonized Tanganyikans. Secondly, no recent systematic and scientific study has been conducted in the areas to explore and examine the role assumed by women warriors, such as Nduna Mkomanile, Namabengo, File and Sanyasi, Gwazera Pasi Mputa Gama, Naupunda Nantabila, Nachanjama, and others, during this protonationalist struggle in German East Africa (Deutch OstAfrika) (Elijah, 2010).

During the Maji Maji war, women participated fully as men did (Kentake, 2015). One of the most influential women who is said to have shown wonderful participation is Nduna Mkomanile who participated in the war by playing various roles, which would have been played by men (Rushohora, 2005). For instance, she is said to have mobilized other women to prepare food for warriors so as to ensure that the battle continues while the warriors 
get basic amenities as usual. That is, it is very obvious that women kept taking care of their families when their husbands were in the battlefield.

This study was guided by the Feminist Theory which is one of the contemporary theories, focusing on the equality that should be observed by the members of the society when ascribing roles (Jones \& Budig, 2008). The theory started to be known in 1995 after the Beijing Conference, which summoned women to discuss their agenda (ibid). Women believe that they are not second human beings when it comes to society. To them, what men do, they can also do.

\section{Literature Review}

There is a need to focus on the role of women during and after the Maji Maji war of 1905-1907 whereby women are still chiefly perceived and categorized as victims, civilians and being in supporting roles for male fighters (Goldstein, 2001). Women are a part of the society and they are recorded to have participated in various societal activities. This section, among other things, discusses the roles of women from the global perspective and particularly during the Maji Maji war, which occurred between 1905 and 1907 both in Ungoni and in its epicenter in Matumbi land/Ngindo areas.

From global context, the role of women in war related matters has been addressed. For instance, in India, women did not stay back during the struggle for freedom, for some of them wore the uniforms and participated to bring about India's freedom in 1947 (Satwinder, 2013; Venkantraman, 2017). Some of significant devotees were Bhìma Bai Holkar, who fought against the British Colonel Malcolm and defeated him in guerrilla warfare and Arun Asaf Ali, who played an outstanding role in the historic "Quit India Movement," launched by Mahatma Gandhi on August 9, 1942 (Satwinder, 2013). The aforementioned women together with other women played a remarkable role in the nationalist struggle of India. In South Africa, some women struggled out of exploitation and oppression. According to Coquery-Vidrovitch (1997), many of those women began working in the textile industries during the wars and learned to know their rights. This shows that they were aware of their common enemy. There was a good example of Garment Workers Union composed of female factory workers who demanded their rights even before 1940.
Zeleza (2007) argues that the documentation of historical change in Africa has been biased against women and that even the regional histories display the same tendencies. Additionally, Olasupo, Isaac and ljeoma (2017) postulate that during the colonial period, women in many African countries, including Nigeria, engaged in substantial anti-colonial nationalist activity. Such activity was generally supported by male nationalist leaders and there was substantial evidence, and certainly historical awareness of this activity on which African historians could draw. This indicates that historiographies regarding women have been affected by lack of gender perspective and this is perhaps one of the reasons as to why women historiographies are invisible in most historical works.

Since women participated in the Maji Maji war of 1905-1907, they possibly assumed some particular roles during the war. The record of the events, however, was done mostly by men. That is, it seems to be a less gender-perspective history, since many authors have not acknowledged women who participated in various wars, including but not limited to the Maji Maji war itself (Rushohora, 2005). This makes women's direct participation as combatants to receive inadequate attention.

Similarly, Olofsson (2018) admits that women were assigned political roles in the country to improve the livelihood of people in the country. In Zimbabwe, women participated as political activists during the liberation struggle for independence. Nevertheless, Rushohora (2005) noted that many historians believed that women were also used as security agents during the war as they relayed information from the enemies to their warriors.

However, during the war, some of women like Nduna Mkomanile from Ngindo land served several other roles (Rushohora, 2005). She inspired the warriors to fearlessly fight against the Germans. That is to say, she was a political activist towards eviction of the German rule in Tanganyika. Other women participated in the war by cooking food, taking medicines and intelligence information to warriors in the battle front (Giblin \& Monson, 2010). However, there are limited sources of literature indicating how specific women participated in the Maji Maji war.

Sadock (n.d) has also noted that one of the major causes for the outbreak of the Maji Maji war was 
the cotton farms established by the German textile manufacturers who were keen to replace American cotton with the cheapest cotton from Africa. Elijah (2010) believed that the hostilities broke out in mid1905, when the Matumbi of Nandete attacked the local Akidas, who were appointed by Germans to work on their behalf and uprooted cotton crops at a nearby plantation. According to Kentake (2015), on July $31^{\text {st }} 1905$, Matumbi men marched on Samanga and destroyed the cotton crop as well as a trading post. Similarly, Ogot and Kieran (1971) was of the opinion that the war spread first throughout the cotton area around the middle and lower Rufiji River, then to Uluguru, the Mahenge Plateau, and the Lukuledi and Kilombero Valleys. The uprising continued as hongo prophets spread Kinjekitile's message of "maji" to Liwale, Dar es Salaam), the Mwera Plateau and eventually into the southern highlands.

On $30^{\text {th }}$ August, 1905, almost 8,000 men of the Mbunga and Pogoro ethnic groups, armed only with spears, tried to assault Mahenge fort, to drag away machine-guns with their bare hands. However, early in September, 1905, the Ngoni joined the rising, but already its first momentum was lost. According to Kentake (2015), an estimated 75,000 people were killed by the Germans during the war and others died of lack of enough food. However, Giblin and Monson (2010) reported that there were 100,000 deaths experienced during the Maji Maji war. It should also be noted that Kinjekitile Ngwale, the prophet who introduced the "maji medicine", was among the people killed during the early stage of the war as the Germans wanted to diffuse the spread of his ideology.

In the Maji Maji war, a total of 66 famous leaders such as Nduna Nkomanile were hanged on trees by the Germans on $27^{\text {th }}$ February, 1907; they were considered to spearhead the revolt against German colonialists (Rushohora, 2005). In the following day, $28^{\text {th }}$ February, 1907 Nduna Songea Luwafu Mbano, who was the Chief of the Ngoni ethnic group, was hanged on a tree, because he rejected to disclose information about his warriors to the Germans as required. As he was being hanged in public, the hanging rope snapped three times. As a result, the Germans shot him dead. Each year, $27^{\text {th }}$ February is observed as Maji Maji commemoration day in Songea Municipality in Ruvuma Region (Rushohora \& Kurmman, 2017). At Maji Maji Memorial Museum in Songea, there is rich evidence of the war and the community always shows deep respect to those who laid down their lives in the war.

\section{Research Methodology}

The research methodology that guided the study is mainly qualitative. To provide a historical exploration and examination on the role of the women in the Maji Maji war, this study used both written and oral primary and secondary historical sources. To make them historical, the information collected have traced the beginning and root cause of the Maji Maji war. The oral information was obtained from the respondents who in one way or another are part and parcel to the historical event under study. The data have been collected through in-depth interviews and consultation with custodians of indigenous histories (Maji Maji Memorial Museum Curator, Maji Maji Elders' Council Member, Nandete Portrait Curator, Cultural Officer - Kilwa District, and Relative Survivors and Custodians of Ngoni people at Namabengo village Namtumbo District Council).

More importantly, under postmodernism, theatre is an important source of historical information where the researcher captured, repeated and observed an imitation of Maji Maji war event. Online YouTube Video Clips about the Maji Maji war, 1905-1907 and the role assumed by women during this event have been systematically transcribed. Some of the aforesaid primary and secondary historical sources have been very useful in accomplishing this important study (Albert, 2010; Anyimadu, 2016; Rushohora, 2005; Rushohora \& Kurmman, 2017).

Further, the data was also collected from archives, museums, documentary reviews, oral testimonies and online sources and analyzed to produce a comprehensive analysis on the role assumed by women in the Maji Maji war in Matumbi land/Ngindo and Ngoniland areas.

\section{Results and Discussion}

According to Maji Maji Memorial Museum Curator, Maji Maji war broke out from 1905 to 1907 . He went further saying, "Women such as Nduna Mkomanile, a sub-chief of Nkosi Chabruma, File and Sanyasi (wives of Nduna Songea Luwafu Mbano), Gwazera Pasi Mputa Gama, Namabengo, Naupunda Nantabila, Nanchanjama, among others, assumed different roles in the areas when the war was fought." This finding is in line with study of Elijah (2010) which reveals that history narrators 
keep saying that women were in the frontline fighting for their lost freedom. Similarly, Kentake (2015) asserts that during the Maji Maji war, women participated fully as men did. Furthermore, Shiraz (1984) and Rushohora and Kurmman (2017) wrote that both men and women warriors organized themselves to fight the Germans.

It is important to note that women prepared conducive environments such as accompanying the war fighters and provision of Magic-medicine for the Maji Maji fighters to wage war against their enemy. During an in-depth interview, The Maji Maji Elders' Council Secretary (an official elder designated by the Maji Maji Elders' Council to keep records, memoirs, meeting minutes, memories and histories regarding the Maji Maji war events) disclosed that:

Women prepared conducive environments for the Maji Maji fighters to wage war against their enemy. For example, Nduna Mkomanile used to receive the people who brought Maji-medicine from Matumbi landKilwa such as Omary Kinjala and Hongo messengers and accompanied them directly to Nkosi Chabruma. Nduna Mkomanile also divided and strategically prepared the Maji Maji war fighting camps for smooth provision of the Magic-medicine in areas such as Old Igumbiro, Kitanda village, Namabengo village, Chandamali and Lundusi.

The Maji Maji Elders' Council is a body or unit formed in 1980 by the Maji Maji Memorial Museum Authority to preserve, among other things, memories and histories of the Maji Maji War, particulars warriors in Ngoniland.

More importantly, women acted as "secret warbearers" in the sense that whatever discussed among the Maji Maji fighters as secret or confidential issues was not disclosed to German troops or militia. During the interview, Nandete Portrait Curator opined that: "Women disclosed whatever considered as German military's secrets to the Maji Maji war fighters, militia, and leaders. Women also prepared food for Maji Maji fighters and husbands who hid into the forests to fight their enemies" (Interview with Nandete Portrait Curator Kilwa).

Similarly, Rushohora (2005) was of the opinion that women contributed greatly during the Maji Maji war of 1905-1907. Furthermore, she said that Nduna Mkomanile mobilized other women to prepare food for warriors so as to ensure that the battle continues while the warriors get basic amenities as usual.

On the same note, women assumed a messengerrole during the war where they carried the Maji Maji information from their leaders to their fighters. Cultural Officer of Kilwa District said that, "Naupunda Nantabila of Nandete-Kilwa, for instance, carried a letter from Kibata to Nandete to inform Ndimi Omcheka on the eruption of the Maji Maji war." This finding is in line with Rushohora (2005) who noted that many historians believed that women were also used as security agents during the war as they relayed information from the enemies to their warriors. More importantly, women used to hide their husbands from being seized or captured by Germans. During an in-depth interview with one of the Relative Survivors and Custodians of Ngoni people at Namabengo village Namtumbo District Council, she had this to say:

There was Namabengo, a businesswoman, who participated directly through hiding men fighting against Germans within her traditional baskets (Jamandas), so German soldiers could not capture them easily. She also provided the fighters with traditional medicines that enabled them to prolong resisting the Germans and medicines for their injury treatment during the war. She continued mobilizing division of work and being industrious within war fightingsocieties and families so that the fighters would not starve in wartime (Interview with Relative Survivors and Custodians of Ngoni people at Namabengo village.

This finding is in line with Rushohora's study (2005) which revealed that Nduna Mkomanile from Ngoniland (Kitanda village) served several other roles such as inspiring warriors to fight fearlessly against the Germans.

Moreover, women accompanied their husband during the war. Such accompaniment was made to bring comfort and encouragement that created more arousal during the battle. During the interview with Maji Maji Memorial Museum Curator, he said that, "File and Sanyasi (wives of Nduna Songea), for example, were very close with their husband in serving him with necessary assistance he needed 
and comforting and encouraging him to proceed with the war at Chandamali hill/caves."

In addition, women assumed the role of taking care of the family members. During the interview with Relative Survivors and Custodians of Ngoni people at Namabengo village - Namtumbo District Council, she said:

Since men were engaged directly in the battle. Women were responsible to feed family members - sons and daughters. They had to fetch water and collected firewood so that to ensure that children were eating some food. However, the kind of food that was mostly preferred during the war was pumpkins.

It is from the presented findings where one may note that the historiography regarding women's roles in Maji Maji war of 1905-1907 might have been affected by various factors such as patriarchal system, culture, and political inheritance. That is the reason as to why many historians have had no records on women participation in struggle for independence and resistance before, during and after independence of Tanganyika in 1961.

\section{Conclusions and Recommendations}

This part presents the conclusions and then gives the recommendations of the study.

\section{Conclusions}

This study has provided in-depth understanding, knowledge and clear picture from a gender and holistic perspective on the roles assumed by women since the onset and initial days of nationalist struggles from German East Africa (Deutch OstAfrika) in 1900s (Maji Maji war 1905-1907) era. Though the war brought negative repercussions like depopulation, destruction of peoples' property, insecurity and other social unrest, it inspired future nationalism in Tanganyika. The mistakes of the early revolutionary leaders and the poor methods of organization were later corrected to give the people of Tanganyika more effective leadership. For example, leaders like Mwalimu Julius Kambarage Nyerere gained a lot from the failure of Maji Maji uprising. He used these lessons to form a national political party called TANU which finally led Tanganyika to political independence on $9^{\text {th }}$ December 1961 and later on the Republic in 1962, which marked the end of the British rule in the country (Egboh \& Aniche, 2015). During the political struggle, women were not left behind. For example, Bibi Titi Mohammed played a great deal toward achievement of freedom in Tanzania.

\section{Recommendations}

It is recommended that women have to be effectively used in building the economy of the nation by being given positions in government and non-government organizations. Since the feminist theorists emphasize on equality, there is need to incorporate women in different sectors, because some of them have shown to have huge ability in terms of leadership. There is also need to have a fair, progressive and authentic historical knowledge in the reconstruction of the past. Nevertheless, because women seem to have little political space, there is a need to continue empowering women so as to realize their full potentials.

\section{References}

Albert, S. (2010). Maji Maji in Ungoni: A reappraisal of the existing historiography.

Anyimadu, A. (2016). Politics and development in Tanzania: Shifting the status quo. Research paper: Chatham House.

Coquery-Vidrovitch, C. (1997). African Women: A Modern History. University of Paris-7 Denis Diderot: Westview Press.

Egboh, E. A., \& Aniche, E. T. (2015). Comparative Politics: An African Viewpoint. Enugu: Rhycee Kerex Publishers.

Elijah, G. (2010). Making History: Historical Narratives of the Maji Maji. Penn History Review, 17(2), 60-77.

Giblin, J., \& Monson, J. (Eds). (2010). Maji Maji Lifting the Frog of War. Leiden, Boston: Brill.

Goldstein, J. S. (2001). War and gender: How Gender shapes the War System and Vice versa. Cambridge University Press.

Jones, K. C., \& Budig, M. J. (2008). Feminist theory. Encyclopedia of Social Problems, Vincent N. Parrillo (Ed): Sage Publications.

Kentake, M. (2015). The Maji Maji War 1905-1907. Retrieved at: https://kentakepage.com/themaji-maji-war-1905-1907/ 
Kumiko, S. (2008). The Matrilineal and Patrilineal Clan Lineages of the Mwera in Southeast Tanzania. Pp. 1-20. Retrieved from file://C:/Users/user/AppData/Local/Temp/ The_Matrilineal_and_Patrilineal_Clan_Linea ges_of_t.pdf.

Kumiko, S. (2014). Comparative Analysis of Women in Female-headed Households and Maleheaded Households: The case of $R Z$ village in Southeast Tanzania, 45-63.

Ogot, B. A., \& Kieran, J. A. (Eds). Zamani: A Survey of East African History. In J, Illife (1971). Tanzania under German and British rule.

Olasupo, O., Isaac, O. O., \& ljeoma, E. O. C. (2017). Nationalism and Nationalist Agitation in Africa: The Nigerian Trajectory. Rev Black Polit Econ, 44(1), 261-283.

Olofsson, L. (2018). Women's Roles in Peace Process: A comparative Study of Women's Participation in the Peace Processes in Africa and West Africa. Published Bachelor of Arts in Peace Development thesis.

Rushohora, N. A. (2005). An Archaeological Identity of the Majimaji: Toward an Historical Archaeology of Resistance to German Colonization in Southern Tanzania. Pretoria: University of Pretoria.
Rushohora, Nancy. A., \& Kurmman. E. (2017). Looking at Majimaji! A Plea for Historical Photographs in Tanzania. African Studies, 77:1, 87-104, DOI: 10.1080/00020184.2017.1395584.

Sadock, M. (n.d). The Maji Maji War and the Prevalence of Diseases in South-eastern Tanzania 1905-1910. http://research.com:8080/xm/ui/handle/20. 500.11810/2309.

Satwinder, K. (2013). Role of Women in India's Struggle for Freedom. International Journal of Management and Social Sciences Research (IJMSSR), 2(4), 112-114.

Shiraz, D. (1984). Maji Maji: The Tanzanian People's War of National Liberation against German Colonialism, 1904-1907. Sauti ya Kamukunji, 3(1), 10-12.

Venkatraman, V. (2017). Women in National Politics and Freedom Struggle. SSRN Electronic Journal, 1-12. Retrieved at: https:www.researchgate.net/publication/32 5868459. DOI: 10.2139/ssrn.31321.

Zeleza, P. T. (2007). The Past and Futures of African Studies and Area Studies: A Generational Inventory. African Historical Review, 39(1), 1-24. DOI: 10.1080/17532520701463364. 